○鈴木豊、青柳優、布施健生、鈴木利久、暮蓮照夫、金 㕌訓、小池吉郎 (山形大学耳悬咽喉科)

【はじめに】

聴神経腫瘍症例の蝸電図所見としてA P の振幅の低下やbroadA P か、従来より報告さ れている。さらに術中およひ術後の螖電図所見において手術侵域に伴うAPの潜時延長・ 振幅の低下があること、およひ聴神経切断後も A P . C M の残存例があることが報告され ている。:今回我々は昭和 61 年以降に当院でおこなわれた手術例のうち、術前術後に蝙電 図検查を施行した症例について検討を行ったので報告した。

【対象およひ方法】

対象は昭和61年7月から平成3年7月まで当院で手術を施行した聴神経腫瘍症例のうち、 術前術後に蝸電図検直を施行した11例11耳である。手術方法は後頭蓋㸗法 7 例、中頭蓋窩 法 5 例であり、腫瘍は全例 $2 \mathrm{~cm}$ 以下の大きさであった。

蝸電図の測定は鼓室内誘導でおこない、刺激音は刺激間隔 75 m secのclickを用い音圧を $90 \sim 0 \mathrm{dBnHLK}$ 変化させた。加算回数は250回、フィルタ帯域 $80 \sim 1500 \mathrm{~Hz}$ と設定しシグナル プロセッサ7T17およひ18を用いて A P およひ P の記録を行った。

【結果】

聴力保存例 (以下”聴保例”と略) は 11 例中 5 例(うち 4 例が頭蓋窝法) であり、術 後照となった症例 (以下”盟例”と略) は6 例であった。蝸電図所見にて術後A P を認め

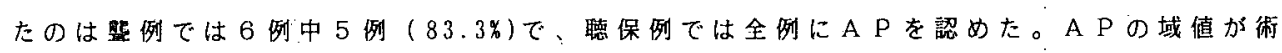
前後に $30 \mathrm{~dB}$ 以上の上昇を認めたのは熊例 1 例、聴保例 2 例であった。また、術後 S P の測 定が可能であった 9 例中に-S P / A P 比の上昇を認めたは 8 例であり、䐅例でより大き な上昇傾向を認めた（図1）。

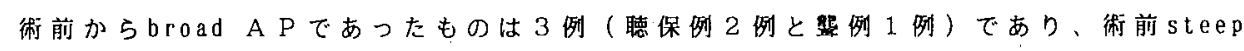
A P であつた 8 例中術後broad A P に变化したのか 4 例（聴保例 1 例、啙例 3 例）であつ た。㯖保例ではsteepのままで A P が残る傾向にあり、照例ではA P 消失の1例を除いて 全例broadA P を認めた。図 2 および図 3 に照例と聴保例各 1 例の術前術後の蜩電図およ ひ A B を提示した。図2（盟例）で は術前のA B R I 波が不明瞭である か、蝸電図では明瞭な A P をを認めた。 術後もAPは残存したか、、振幅の著明 な低下を認めた。四 3 (聴保例)で もA P 振幅の低下を認めるが軽度で あった。また 2 症例とも術後 N 2 の振幅 低下を認めた。

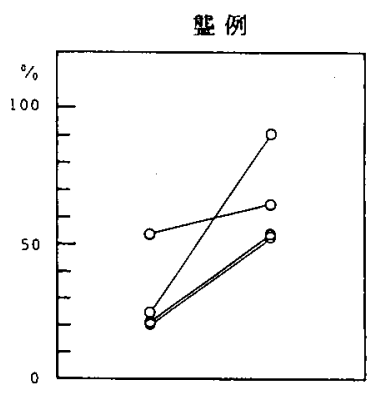

術前術後 図1-SP/AP比の術前術後の変化 


\section{[考察 )}

聴神経腫呁の術後に照となつた例でも A P を認める症例は多かつたが、聴保例に比較し て熊例では術後に A P 振幅の低下がより著明であるため、結果としてーS P / A P 比が上 䄯する傾向が認められた。また、A B R のI波か消失しなから A P ( N 1) が残存してい ることは、これらの反応が必ずしも同一の起源でないことを示唆する所見と考えられた。 さらに、聴保例・盟例ともにN 2 の消失を認めたことは、手術操作による何らかの影響が 考えられた。

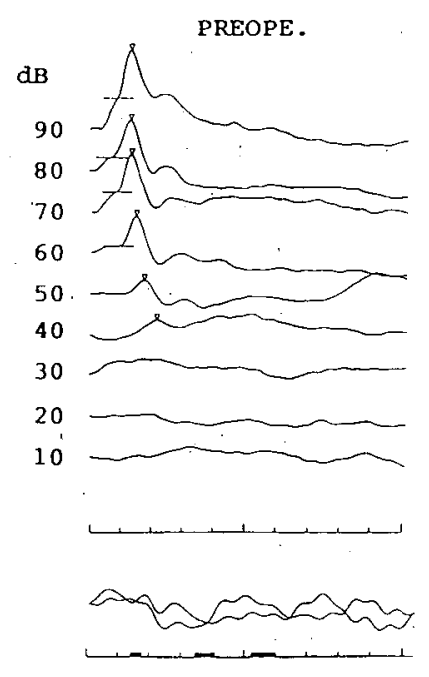

PREOPE.
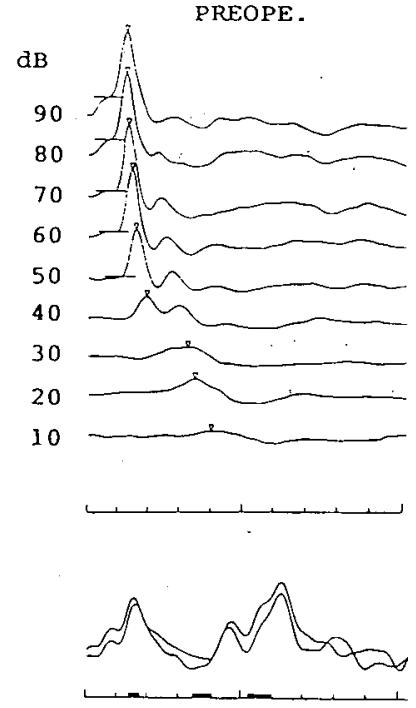

POSTOPE.
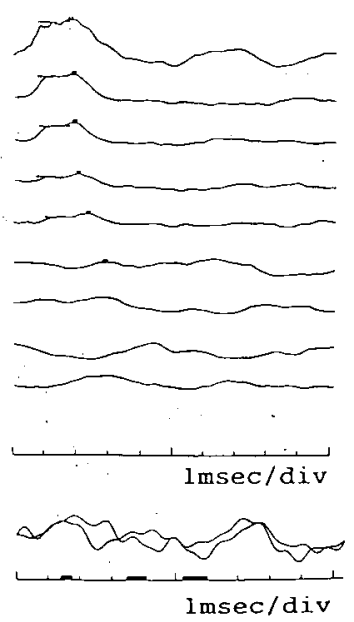

POSTOPE.
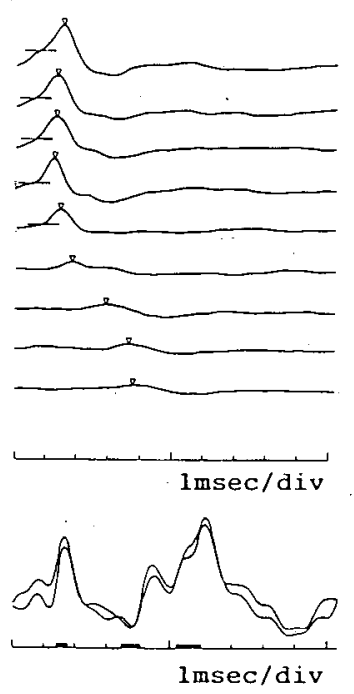

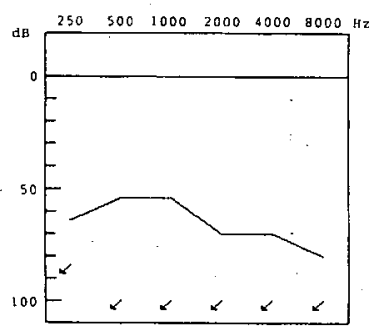

図 2 並例の術前術後の 蝸電図およひA B R 術前㯖力

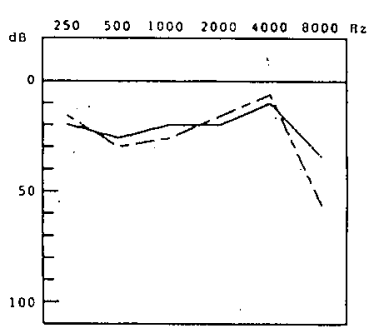

図 3 聴保例の術前術後の 蝸電図および A B R 術前聴力 術後 聴力 